\title{
Advantages of a New Taq DNA Polymerase in Multiplex PCR and Time-Release PCR
}

\author{
C. Kebelmann-Betzing, K. Seeger, S. Dragon, G. Schmitt, A. Möricke, T.A. Schild"1, \\ G. Henze and B. Beyermann \\ Virchow Medical Center Charité, Humboldt-University, Berlin and ${ }^{1} \mathrm{PE}$ Applied \\ Biosystems GmbH, Weiterstadt, Germany
}

BioTechniques 24:154-158 (January 1998

\begin{abstract}
Extensive diagnostic and scientific investigations are often restricted by limited availability of material. Therefore, methods like multiplex PCR strategies are needed to conserve as much sample as possible. Unfortunately, the establishment of such procedures poses several difficulties. Here we describe the advantages of a new enzyme, AmpliTaq Gold ${ }^{\mathrm{TM}}$ DNA Polymerase, in multiplex and time-release PCR. The application of this thermostable recombinant Taq DNA polymerase allows the specific amplification of DNA/cDNA targets with very high sensitivity. With our protocol, the specific amplification of 13 different cDNAs of cytokines and cytokine receptors can be realized in three multiplex PCRs (IL-2R $\alpha, I L-2 / 15 R \beta, \gamma_{C^{-}}$

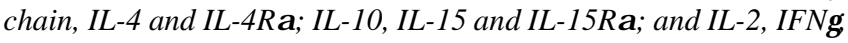
$I L-7, I L-7 R \alpha$ and $I L-9 R \alpha)$. The novel application of AmpliTaq Gold DNA Polymerase in a time-release PCR protocol allows specific amplification of target DNA/cDNA when only limited amounts of material are available or only low-copy-number DNA/cDNA is suspected. No IL-9 cDNA can be detected in peripheral blood mononuclear cells $(P B M C)$ in the absence of any stimulation, thus it was difficult to amplify this target with routine PCR protocols. Here we demonstrate the reliable and reproducible amplification of IL-9 cDNA in the Hodgkin's lymphoma cell line KM-H2, in PBMC and in stimulated PBMC. Results with AmpliTaq Gold DNA Polymerase were more sensitive and specific compared with AmpliTaq ${ }^{\circledR}$ DNA Polymerase, with and without manual hot-start procedure.
\end{abstract}

\section{INTRODUCTION}

Over the past 10 years, the polymerase chain reaction (PCR) has become one of the key procedures in molecular science and in molecular diagnostics. Its tremendous sensitiv- ity allows detection of a single molecule with a specific DNA sequence in more than 100000 genomes. Although the PCR is conceptionally simple and basically depends on the use of a heat-stable DNA polymerase (15), several additional factors have to be optimized. For successful and sensitive amplification of a specific DNA/cDNA target, the first few reaction cycles are especially crucial (16). If reaction components are mixed at low or permissive temperature $\left(4^{\circ}-25^{\circ} \mathrm{C}\right)$, nonspecific primer annealing and extension can occur (3), which results in misprimed products and primer oligomers. The manual hot-start procedure was developed to circumvent those problems (5). Unfortunately, addition of the missing key reactant to the reaction at temperatures between $60^{\circ}$ and $80^{\circ} \mathrm{C}$ is very inconvenient and prone to carryover.

Here we describe the advantages of a new enzyme, AmpliTaq Gold ${ }^{\mathrm{TM}}$ DNA Polymerase, in the specific amplification of 13 cDNAs of cytokines and cytokine receptors in three multiplex PCRs [( $i$ ) Interleukin (IL)-2 receptor (R) $\alpha$, IL-2/15R $\beta$, common $\gamma$-chain $\left(\gamma_{c}\right)$, IL-4 and IL-4R $\alpha$; (ii) IL-10, IL-15 and IL-15R $\alpha$; and (iii) IL-2, interferon-gamma (IFN $\gamma$ ), IL-7, IL$7 \mathrm{R} \alpha$ and IL-9R $\alpha]$ in comparison with conventional AmpliTaq ${ }^{\circledR}$ DNA Polymerase, with and without manual hot start.

This thermostable DNA polymerase is a modified recombinant form of Taq DNA polymerase and is provided in an inactive state. It regains activity at temperatures above those suitable for primer annealing and is activated irreversibly by adding a pre-PCR heat step at $92^{\circ}-95^{\circ} \mathrm{C}$ for $9-12 \mathrm{~min}$.

Furthermore, we demonstrate a new application of AmpliTaq Gold DNA Polymerase in a time-release PCR protocol. In time-release PCR, the enzyme is activated gradually during thermal cycling, allowing the amplification of low-copy-number DNA/cDNA with very high sensitivity. This enables the reliable and reproducible amplification of IL-9 cDNA in the 
Table 1. Multiplex and Time-Release PCR: Product Length, PCR Primer Sequences and Cytokine/Cytokine-Receptor Gene Location

\begin{tabular}{|c|c|c|c|}
\hline \multirow{2}{*}{$\begin{array}{l}\text { PCR } \\
\text { Product }\end{array}$} & \multirow[b]{2}{*}{ bp } & Primer Forward/Reverse & \multirow{2}{*}{$\begin{array}{l}\text { Gene } \\
\text { Locus }\end{array}$} \\
\hline & & $\rightarrow$ & \\
\hline \multicolumn{4}{|c|}{ Multiplex PCR I } \\
\hline IL-4 & 268 & $\begin{array}{l}\text { ACA gAg CAg AAg ACT CTg Tg } \\
\text { TCT ggT Tgg CTT CCT TCA CA }\end{array}$ & $5 q 23-31$ \\
\hline *IL-2R $\alpha$ & 312 & $\begin{array}{l}\text { CCT gCC TCg TCA CAA CAA CA } \\
\text { AAA ACg CAg gCA AgC ACA AC }\end{array}$ & 10p15-14 \\
\hline $\begin{array}{l}{ }^{*} \mathrm{IL}-2 \mathrm{R} \beta \\
\mathrm{IL}-15 \mathrm{R} \beta\end{array}$ & 389 & $\begin{array}{l}\text { TCA AAC AAC ATT CCA CCC CA } \\
\text { CAA ATg gTC AgC AgC CCT CT }\end{array}$ & $\begin{array}{l}22 q 11.2- \\
13\end{array}$ \\
\hline$\gamma_{c}$ & 432 & $\begin{array}{l}\text { AAA ACT gCA gAA TCT ggT gAT CCC } \\
\text { ggT ggg AAT TCg ggg CAT CgT C }\end{array}$ & Xq13.1 \\
\hline${ }^{*} \mathrm{GAPDH}$ & 566 & $\begin{array}{l}\text { gCA ggg ggg AgC CAA AAg gg } \\
\text { TgC CAg CCC CAg CgT CAA Ag }\end{array}$ & $12 q 13$ \\
\hline IL-4R $\alpha$ & 776 & $\begin{array}{l}\text { ACC CgT ATC CCC CTg ACA A } \\
\text { CAC AAT gCC CTC CCT TCC }\end{array}$ & $\begin{array}{l}16 \mathrm{p} 11.2- \\
12.1\end{array}$ \\
\hline \multicolumn{4}{|c|}{ Multiplex PCR II } \\
\hline $\mathrm{IL}-15$ & 327 & $\begin{array}{l}\text { CTT gCC ATA gCC AgC TCT TCT TCA } \\
\text { TCC TCC AgT TCC TCA CAT TCT TTg }\end{array}$ & $4 q 31$ \\
\hline${ }^{*} \mid \mathrm{L}-10$ & 351 & $\begin{array}{l}\text { CTg AgA ACC AAg ACC CAg ACA TCA } \\
\text { Agg CAA TAA ggT TTC TCA Agg ggC Tgg }\end{array}$ & 1 \\
\hline$\beta$-actin & 403 & $\begin{array}{l}\text { CCT TCC Tgg gCA Tgg AgT CCT } \\
\text { AAT CTC ATC TTg TTT TCT gCg }\end{array}$ & $7 q 22$ \\
\hline IL-15R $\alpha$ & 630 & $\begin{array}{l}\text { CgC CAg gTg TgT ATC CAC } \\
\text { ACA gAg AgC TTT ggg TAT gTC AC }\end{array}$ & 10p15-14 \\
\hline \multicolumn{4}{|c|}{ Multiplex PCR III } \\
\hline *|L-2 & 340 & $\begin{array}{l}\text { ССТ CAA СTC CTg CCA CAA Tg } \\
\text { TTg CTg ATT AAg TCC CTg gg }\end{array}$ & $4 q 26-27$ \\
\hline *|L-7 & 429 & $\begin{array}{l}\text { TTT TAT TCC gTg CTg CTC gC } \\
\text { gCC CTA ATC CgT TTT gAC CA }\end{array}$ & $8 q 12-13$ \\
\hline${ }^{*} \mathrm{IFN} \gamma$ & 477 & $\begin{array}{l}\text { TCg TTT Tgg gTT CTC TTg gC } \\
\text { gCA ggC Agg ACA ACC ATT AC }\end{array}$ & $12 \mathrm{q} 24.1$ \\
\hline IL-9R $\alpha$ & 607 & $\begin{array}{l}\text { AgT gCT CgT gCC ATC TgA C } \\
\text { gAA gAA CAT CgC Tgg AgA gg }\end{array}$ & $\mathrm{Xq}$ \\
\hline IL-7R $\alpha$ & 740 & $\begin{array}{l}\text { CTC CAg AgA TCA ATA ATA gCT C } \\
\text { TTg TCg CTC ACg gTA AgT TCA }\end{array}$ & $5 p 13$ \\
\hline \multicolumn{4}{|c|}{ Time-Release PCR } \\
\hline IL-9 & 201 & $\begin{array}{l}\text { Cgg ggA TCC Tgg ACA TCA AC } \\
\text { CCC gAC TgA AAA TCA gTg gg }\end{array}$ & $5 q 31.1$ \\
\hline $\begin{array}{l}\text { Oligonucl } \\
\text { described }\end{array}$ & $\begin{array}{l}\text { leotid } \\
\text { d by P }\end{array}$ & $\begin{array}{l}\text { orimer sequences indicated with }\left(^{*}\right) \text { were } \\
\text { tzer et al. (12). }\end{array}$ & previously \\
\hline
\end{tabular}

Hodgkin's lymphoma cell line KM-H2, peripheral blood mononuclear cells (PBMC) and phorbol 12-myristate 13-acetate (PMA)-stimulated PBMC.

With respect to investigation of hematological disorders, IL-2, IL-4, IL-7, IL-9 and IL-15 and IL-10 as a suppression factor of cytokine production in CD4+, CD8+ T cells and natural killer (NK) cells are of interest. The receptors of these cytokines, apart from the IL-10 receptor, belong to a hematopoietic receptor superfamily characterized by sharing the common $\gamma$-chain $\left(\gamma_{c}\right)$, which is required for effective signal transduction (10). Defects of cytokine and cytokine-receptor genes are associated with a number of diseases, tumor growth and decreased tumor defense mechanisms $(1,7-9,11,17)$.

\section{MATERIALS AND METHODS}

Human PBMC were isolated from blood of healthy donors by Ficoll ${ }^{\circledR}$ density gradient centrifugation (Seromed ${ }^{\circledR}$; Biochrom KG, Berlin, Germany). To detect IL-9 cDNA, PBMC were stimulated with PMA (Sigma-Aldrich Chemie $\mathrm{GmbH}$, Deisenhofen, Germany) at a concentration of $2 \mathrm{ng} / \mathrm{mL}$ for 24 h. The cell line KM-H2 (human Hodgkin's lymphoma; DSM ACC 8) was obtained from DSMZ, German Collection of Microorganism and Cell Cultures (Braunschweig, Germany).

Total cellular RNA was isolated from $1 \times 10^{7} \mathrm{PBMC}$ and $\mathrm{KM}-\mathrm{H} 2$ cells by an RNeasy ${ }^{\circledR}$ Kit (Qiagen GmbH, Hilden, Germany). Reverse transcription (RT) into cDNA was performed in a $40-\mu \mathrm{L}$ reaction containing $100 \mathrm{pM}$ hexanucleotides (Boehringer Mannheim GmbH, Mannheim, Germany); first-strand buffer; $5 \mathrm{mM}$ dithiothreitol (DTT); $500 \mu \mathrm{M}$ of each dATP, dGTP, dCTP and dTTP; and $400 \mathrm{U}$ of SUPERSCRIPT $^{\mathrm{TM}}$ II H- Reverse Transcriptase (all from Life Technologies $\mathrm{GmbH}$, Eggenstein, Germany). The reaction mixture was incubated at $37^{\circ} \mathrm{C}$ for $45 \mathrm{~min}$ and inactivated at $94^{\circ} \mathrm{C}$ for 5 min.

Altogether nine multiplex PCRs were performed. The efficiency of both AmpliTaq Gold DNA Polymerase and AmpliTaq DNA Polymerase (both from PE Applied Biosystems $\mathrm{GmbH}$, Weiterstadt, Germany), with and without manual hotstart procedure, was compared in three different assays consisting of three multiplex PCRs. For each assay, an identical master mixture was prepared containing $9 \mu \mathrm{L}$ GeneAmp ${ }^{\circledR}$ $10 \times$ PCR buffer $\left[15 \mathrm{mM} \mathrm{MgCl}_{2}, 500 \mathrm{mM} \mathrm{KCl}, 100 \mathrm{mM}\right.$ Tris$\mathrm{HCl}, \mathrm{pH} 8.3,0.01 \%$ (wt/vol) gelatin] (PE Applied Biosystems), $9 \mu \mathrm{L} 2 \mathrm{mM}$ dNTP-Mix (Life Technologies) and $3 \mu \mathrm{L}$ cDNA mixture of PBMC.

Then either $3 \mathrm{U}$ AmpliTaq Gold or $3 \mathrm{U}$ AmpliTaq were added, respectively. Only for manual hot-start using AmpliTaq, the enzyme was added to the reaction mixture at $94^{\circ} \mathrm{C}$ during initial denaturation. Finally, the master mixture was divided into three equal 7.2- $\mu \mathrm{L}$ aliquots and the following combinations of specific oligonucleotide primer pairs (TIB Molbiol GmbH, Berlin, Germany) were added to each tube: Tube 1: 40 pmol IL-4, 30 pmol IL-2R $\alpha, 10$ pmol IL-2/15R $\beta, 5$ pmol $\gamma_{c}, 5$ pmol glyceraldehyde phosphate dehydrogenase (GAPDH) and 30 pmol IL-4R $\alpha$; Tube 2: 30 pmol IL-15, 30 pmol IL-10, 5 pmol $\beta$-actin and 30 pmol IL-15R $\alpha$; Tube 3: 40 pmol IL-2, 40 pmol IL-7, 5 pmol IFN $\gamma, 40$ pmol IL-9R $\alpha$ and 20 pmol IL-7R $\alpha$. Each multiplex PCR was performed in a $30-\mu \mathrm{L}$ reaction volume. Table 1 lists the primer pairs for the amplification of the investigated cytokines and cytokine receptors as well as the corresponding PCR product lengths and the gene locations. The primer pairs for the amplification of IFN $\gamma$, IL-2, IL-4, IL-10, IL-2R $\alpha$ and IL-2/15R $\beta$ were previously described by Platzer et al. (12).

The multiplex PCR mixtures were first amplified for $5 \mathrm{cy}-$ cles, with denaturation at $94^{\circ} \mathrm{C}$ for $1 \mathrm{~min}$, primer annealing at $62^{\circ} \mathrm{C}$ for $45 \mathrm{~s}$ and primer extension at $72^{\circ} \mathrm{C}$ for $1 \mathrm{~min}, 25 \mathrm{~s}$. The reaction mixtures were then amplified for 29 cycles with denaturation at $94^{\circ} \mathrm{C}$ for $1 \mathrm{~min}$, primer annealing at $62^{\circ} \mathrm{C}$ for $30 \mathrm{~s}$, primer extension at $72^{\circ} \mathrm{C}$ for $45 \mathrm{~s}$ and a final extension step at $72^{\circ} \mathrm{C}$ for $10 \mathrm{~min}$. Initial denaturation for cDNA amplification with AmpliTaq was 5 min. For AmpliTaq Gold, the 
required 10-min pre-activation step at $94^{\circ} \mathrm{C}$ was performed.

Three different time-release PCR assays for the detection of IL-9 cDNA in PBMC (PMA \pm ) and KM-H2 cells were performed to compare AmpliTaq Gold with AmpliTaq, with and without manual hot-start procedure. For each assay, a master mixture was prepared containing $9 \mu \mathrm{L}$ GeneAmp 10× PCR buffer, $9 \mu \mathrm{L}$ dNTP-Mix, 30 pmol of each $5^{\prime}$ - and $3^{\prime}$-specific IL-9 oligonucleotide primers (see Table 1) and either $3 \mathrm{U}$ AmpliTaq Gold or 3 U AmpliTaq, respectively. In the manual hot-start procedure, AmpliTaq was added to the reaction mixture at $94^{\circ} \mathrm{C}$ during initial denaturation. Finally, the master mixture was divided into three $8.2-\mu \mathrm{L}$ aliquots, and $1 \mu \mathrm{L}$ cDNA of KM-H2 cells, PBMC or stimulated PBMC was added. All time-release PCRs were carried out in a $30-\mu \mathrm{L}$ reaction volume.

Cycle conditions were established as follows: after pre-activation at $94^{\circ} \mathrm{C}$ for $3 \mathrm{~min}, 60$ cycles of primer annealing at $65^{\circ} \mathrm{C}$ for $30 \mathrm{~s}$, elongation at $72^{\circ} \mathrm{C}$ for $1 \mathrm{~min}$ and denaturation at $94^{\circ} \mathrm{C}$ for $1 \mathrm{~min}$ were performed, followed by a final extension step at $72^{\circ} \mathrm{C}$ for $10 \mathrm{~min}$.

PCRs were performed in a DNA Engine ${ }^{\mathrm{TM}}$ PTC-200 Thermal Cycler (MJ Research, Watertown, MA, USA). The PCR products were separated by electrophoresis on a $2 \%$ MetaPhor ${ }^{\mathrm{TM}}$ Agarose Gel (FMC BioProducts, Rockland, ME, USA) with $120 \mathrm{~V}$ for $1 \mathrm{~h}, 30 \mathrm{~min}$ at $4^{\circ} \mathrm{C}$ and stained with ethidium bromide (Sigma-Aldrich Chemie). Gels were photographed with the Gel Doc $1000^{\mathrm{TM}}$ Gel Documentation System and analyzed with Molecular Analyst ${ }^{\circledR}$ Software Version 1.4 (both from Bio-Rad GmbH, Munich, Germany).

The sequences of all PCR products were confirmed by direct sequencing using the DNA Sequencing Kit and the ABI PRISM $^{\mathrm{TM}} 377$ DNA Sequencer (both from PE Applied Biosystems) (data not shown).

\section{RESULTS AND DISCUSSION}

With the advent of PCR technology for analysis of DNA/cDNA, it is feasible to perform studies on low number of cells. Furthermore, molecular-genetic results can be obtained within a short time. Nevertheless, although only small amounts of material are required for each PCR analysis, extensive diagnostic and scientific investigations are often restricted by limited availability of material. Therefore, economical methods are needed to conserve as much patient sample as possible. Multiplex PCR strategies offer this potential, but unfortunately, the establishment of such procedures poses several difficulties. Yet, these can be minimized by the application of the new AmpliTaq Gold DNA Polymerase.

The majority of the multiplex PCR systems described previously have been established to amplify genomic DNA simultaneously. Birch et al. (2) have already demonstrated the benefit of AmpliTaq Gold DNA Polymerase in the amplification of viral genome [human immunodeficiency virus Type 1 (HIV-1)], of small ribosomal RNA subunits from Mycobacterium tuberculosis and the co-amplification of cystic fibrosis genes.

In this study, three multiplex PCRs were designed to amplify a large number of cytokine/cytokine-receptor cDNAs in human PBMC to simplify and to accelerate the investigation of these cytokines in diagnostics and research. For the multiplex PCRs, all oligonucleotide primers were complementary to sequences contained in the coding sequence of each gene and were designed to attain similar melting temperatures $\left(T_{m}\right)$. They were chosen to span different exons and optimized using the OLIGO ${ }^{\mathrm{TM}}$ program (14).

Furthermore, different PCR product lengths were selected to distinguish between the amplified products by agarose gel electrophoresis. Thereafter, PCR conditions were primarily established for each product separately by optimizing annealing temperatures, primer concentrations, reaction buffers (i.e., concentration of monovalent cations) and PCR kinetics.

The intention was to establish three different multiplex PCRs by combining, in the first tube, IL-2, IL-4 and their corresponding receptors (IL-2R $\alpha$, IL-2/15R $\beta, \gamma_{c}$, and IL-4R $\alpha$ ); in the second tube, IL-15, IL-15R $\alpha$ and IL-10; and in the third tube, IFN $\gamma$, IL-7, IL-9 and the corresponding receptors IL$7 \mathrm{R} \alpha$ and IL-9R $\alpha$. However, IL-2 could not be included in the first PCR, because the amplified products of IL- 2 and IL- $2 R \alpha$ could not be separated distinctly by gel electrophoresis. Thus, IL-2 was included in tube 3. Because of difficulties detecting IL-9 cDNA in human PBMC, it had to be excluded from the multiplex PCR system. The integrity of cDNA was controlled by internal amplification of GAPDH (Figure 1, lanes 1, 4 and 7) or $\beta$-actin (Figure 1, lanes 2, 5 and 8) cDNA as shown. Both GAPDH or $\beta$-actin can serve as positive control in the multiplex PCRs.

Although PCR conditions for the amplification of each single cDNA had been carefully established, further adaptations were required for the multiplex PCRs. To achieve the same PCR condition for each assay, annealing temperatures, reaction buffers and cycle conditions were adapted. For the simultaneous amplification of longer fragments with identical efficiency as in single PCR, the elongation time had to be prolonged. Most importantly, in the final adjustment of multiplex PCR, the concentration of each individual primer had to be

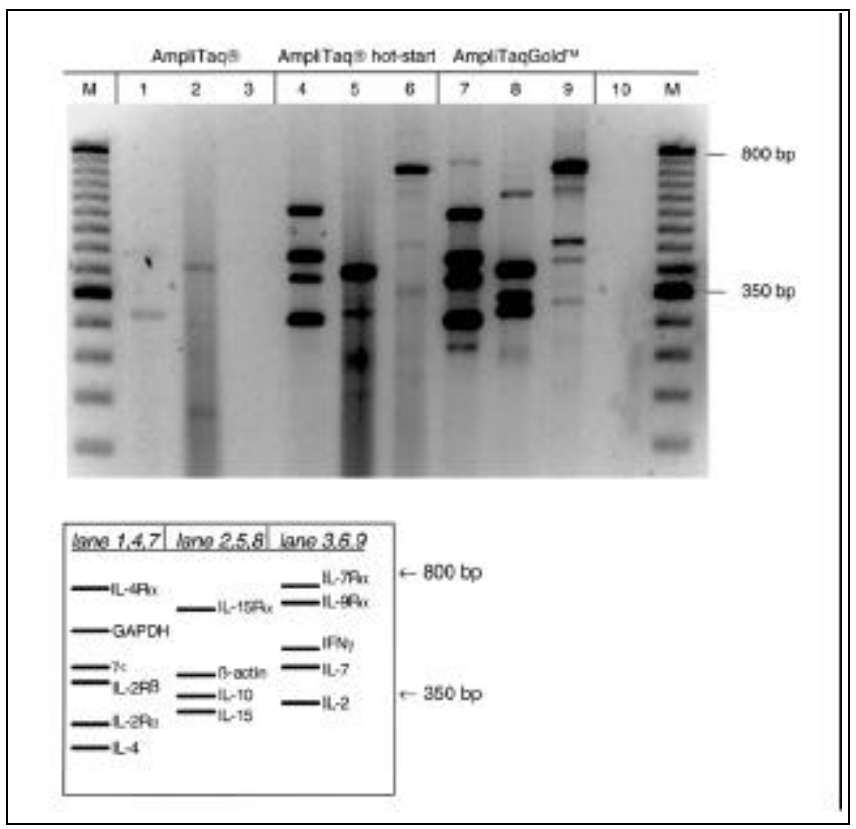

Figure 1. Multiplex PCR cDNA amplification of the investigated cytokine/cytokine receptors. Lanes 1-3: AmpliTaq DNA Polymerase; lanes 4-6: AmpliTaq and manual hot start; lanes 7-9: AmpliTaq Gold DNA Polymerase; marker (M): 50-bp DNA ladder; lane 10: negative control. Lanes 1, 4 and 7: IL-4, IL-2R $\alpha$, IL-2/15R $\beta, \gamma_{c}$, GAPDH and IL-4R $\alpha$; lanes 2, 5 and 8: IL-15, IL-10, $\beta$-actin and IL-15R $\alpha$; lanes 3, 6 and 9: IL-2, IL-7, IFN $\gamma$, IL-9R $\alpha$ and IL-7R $\alpha$; PCR products were separated on a $2 \%$ MetaPhor agarose gel. 
gradually determined. Besides optimal reaction conditions, this turned out to be crucial for the sensitivity of the multiplex PCR. The application of denaturing agents such as dimethyl sulfoxide (DMSO), glycerol and formamide in the multiplex PCR assays did not improve the amplification specifity.

The manual hot-start PCR is a widely used method that is recommended for multiplex PCR protocols to achieve higher template specificity. Generally, the application of manual hotstart methods leads to improved specificity (Figure 1, lanes 4, 5 and 6) compared to standard PCR procedures using Taq DNA polymerases, wherein even positive controls, e.g., GAPDH or $\beta$-actin, are poorly detectable (Figure 1, lanes 1, 2 and 3). Yet, the amplifications with AmpliTaq DNA Polymerase were less efficient than those using AmpliTaq Gold DNA Polymerase (Figure 1, lanes 7, 8 and 9). Results with AmpliTaq Gold were even more sensitive and specific compared with manual hot-start PCR.

The new application of AmpliTaq Gold in a time-release PCR enabled the reliable and reproducible amplification of IL9 cDNA in the Hodgkin's lymphoma cell line KM-H2, PBMC and stimulated PBMC. No IL-9 cDNA can be detected in PBMC in the absence of any stimulation or after B-cell or monocyte activation, thus it was difficult to amplify this target with routine protocols $(4,6,13)$. Houssiau et al. previously demonstrated IL-9 mRNA induction in human T cells stimulated with PMA for $28 \mathrm{~h}$. The induction of the IL-9 gene requires a cytokine cascade involving IL-2, IL-4 and IL-10 (6).

For the detection of IL-9 cDNA by time-release PCR, the initial denaturation was reduced to $3 \mathrm{~min}$, and 26 additional cycles were added that allowed slow activation of AmpliTaq Gold during thermal cycling (time-release). The same reaction conditions were used for the amplification with AmpliTaq, with or without manual hot-start procedure. Comparison of results revealed a higher specific yield and lower background with AmpliTaq Gold in contrast to amplification with AmpliTaq and manual hot-start PCR (see Figure 2).

KM-H2 cells are known to have detectable IL-9 cDNA, thus amplification is even possible with standard PCR protocols using conventional AmpliTaq, and nonspecific amplifications are rare (see faint band in Figure 2, lane 1). Manual hot-start PCR facilitates the amplification of IL-9 cDNA in

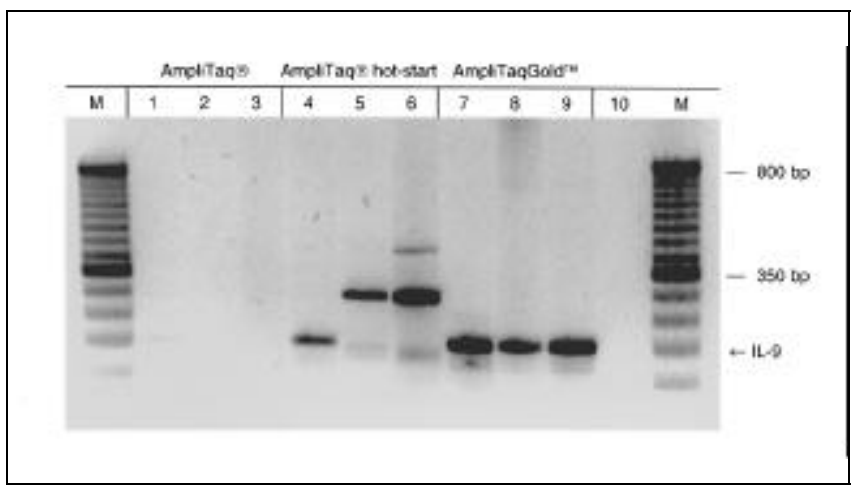

Figure 2. Time-release PCR amplification of IL-9 cDNA in KM-H2, PBMC and PMA-stimulated PBMC. Lanes 1-3: AmpliTaq DNA Polymerase; lanes 4-6: AmpliTaq and manual hot start; lanes 7-9: AmpliTaq Gold DNA Polymerase; marker (M): 50-bp DNA ladder; lane 10: negative control. Lanes 1, 4 and 7: IL-9 in KM-H2 cells; lanes 2, 5 and 8: IL-9 in nonstimulated PBMC; lanes 3, 6 and 9: IL-9 in PMA-stimulated PBMC. The intense PCR products (ca. $300 \mathrm{bp}$ ) in lanes 5 and 6 are nonspecific amplification products as confirmed by direct sequencing (data not shown). PCR products were separated on a $2 \%$ MetaPhor agarose gel. 
KM-H2 cells clearly (Figure 2, lane 4). As expected, no IL-9 cDNA was detected in non-stimulated PBMC. In contrast to Houssiau et al. (6), we could not observe IL-9 cDNA in PBMC (PMA+) either in standard PCR or in manual hot-start procedure using AmpliTaq (Figure 2, lanes 2 and 3), which may be due to the shorter PMA-stimulation period. Surprisingly, in manual hot-start PCR, only nonspecific amplification products could be detected (intense PCR product of ca. 300 bp in Figure 2, lanes 5 and 6) as confirmed by direct sequencing. The application of AmpliTaq Gold increases the specific amplification of IL-9 cDNA in KM-H2 cells, PMAactivated PBMC and even impressively in PBMC without prior stimulation, as shown in Figure 2, lanes 6, 7 and 8. In fact, there were just a few differences in IL-9 product intensity between KM-H2 cells, PBMC and stimulated PBMC. This reaffirms the amplification efficiency of AmpliTaq Gold, even when only few amounts of specific primer binding sites (i.e., in PBMC) are available.

In conclusion, AmpliTaq Gold DNA Polymerase improves the requirements of sensitive and specific amplification of target DNA/cDNA. This is especially desirable in post-PCR procedures like direct sequencing of PCR products, quantitative PCR analysis, cloning of PCR products or in single-cell and in situ PCR. Furthermore, time-release PCR allows specific amplification of target DNA/cDNA when only limited amounts of material are available, for instance in analysis of nucleic acids from blood smears or tissue slides and in forensic investigations.

\section{ACKNOWLEDGMENTS}

This work was supported by a grant of the Deutsche Krebshilfe e.V., Bonn, Germany. Mr. Kebelmann-Betzing and Mrs. Möricke received a fellowship by the Kind-Philipp-Stiftung für Leukämieforschung, Essen, Germany.

\section{REFERENCES}

1.Baird, P.N., R.J. D’Andrea and G.J. Goodall. 1995. Cytokine receptor genes: structure, chromosomal location and involvement in human disease. Leuk. Lymphoma 18:373-383.

2.Birch, D.E., L. Kolmodin, J. Wong, G.A. Zangenberg, M.A. Zoccoli, N. McKinney, K.K.Y. Young and W.J. Laird. 1996. Simplified hot start PCR. Nature 381:445-446.

3.Chou, Q., M. Russel, D.E. Birch, J. Raymond and W. Bloch. 1992. Prevention of pre-PCR mis-priming and primer dimerization improves lowcopy-number amplifications. Nucleic Acids Res. 11:1717-1723.

4.Cluitmans, F.H., B.H. Esendam, J.E. Landegent, R. Willemze and J.H. Falkenburg. 1995. Constitutive in vivo cytokine and hematopoietic growth factor gene expression in the bone marrow and peripheral blood of healthy individuals. Blood 85:2038-2044.

5.D’Aquila, R.T., L.J. Bechtel, J.A. Videler, J.J. Eron, P. Gorczyca and J.C. Kaplan. 1991. Maximizing sensitivity and specificity of PCR by preamplification heating. Nucleic Acids Res. 19:3749

6.Houssiau, F.A., L. Schandene, M. Stevens, C. Cambiaso, M. Goldman, J. van Snick and J.C. Renauld. 1995. A cascade of cytokines is responsible for IL-9 expression in human T cells. Involvement of IL-2, IL-4, and IL-10. J. Immunol. 154:2624-2630.

7.Matthew, D.J., P.A. Clark, J. Herbert, G. Morgan, R.J. Armitage, C. Kinnon, A. Minty, K.H. Grabstein, D. Caput, P. Ferrara et al. 1995. Function of the interleukin-2 (IL-2) receptor gamma chain in biologic responses of X-linked severe combined immunodeficient B cells to IL-2, IL-4, IL-13 and IL-15. Blood 85:38-42.

8.Merz, H., F.A. Houssiau, K. Orscheschek, J.C. Renauld, A. Fliedner, M. Herin, H. Noel, M. Kadin, H.K. Mueller-Hermelink, J. van Snick et al. 1991. Interleukin-9 expression in human malignant lymphomas: unique association with Hodgkin's disease and large cell anaplastic lymphoma. Blood 78:1311-1317.

9.Michiel, D.F. and J.J. Oppenheim. 1992. Cytokines as positive and negative regulators of tumor promotion and progression. Cancer Biol. 3:3-15.

10.Miyajima, A., T. Kitamura, N. Harada, T. Yokota and K. Arai. 1992. Cytokine receptors and signal transduction. Annu. Rev. Immunol. 10:295331.

11.Noguchi, M., H. Yi, H.M. Rosenblatt, A.H. Filipovich, S. Adelstein, W.S. Modi, O.W. McBride and W.J. Leonard. 1993. Interleukin-2 receptor gamma chain mutation results in X-linked severe combined immunodeficiency in humans. Cell 73:147-157.

12.Platzer, C., S. Ode-Hakim, P. Reinke, W.-D. Döcke, R. Ewert and H.D. Volk. 1994. Quantitative PCR analysis of cytokine transcription patterns in peripheral mononuclear cells after anti-CD3 rejection therapy using two novel multispecific competitor fragments. Transplantation 58:264-268.

13.Renauld, J.C. and J. van Snick. 1994. Chapter 11, p. 209-221. The Cytokine Handbook, 2nd ed. Academic Press, London.

14.Rychlik, W. and R.E. Rhoads. 1989. A computer program for choosing optimal oligonucleotides for filter hybridization, sequencing and in vitro amplification of DNA. Nucleic Acids Res. 17:8543-8551

15.Saiki, R.K., D.H. Gelfand, S. Stoffel, S.J. Scharf, R. Higuchi, G.T. Horn, K.B. Mullis and H.A. Erlich. 1988. Primer-directed enzymatic amplification of DNA with a thermostable DNA polymerase. Science 239:487-491.

16.Wu, D.Y., L. Ugozzoli, B.K. Pal, J. Qian and R.B. Wallace. 1991. The effect of temperature and oligonucleotide primer length on the specificity and efficiency of amplification by the polymerase chain reaction. DNA Cell Biol. 10:233-238.

17.Yamamura, M., R.L. Modlin, J.D. Ohmen and R.L. Moy. 1993. Local expression of antiinflammatory cytokines in cancer. J. Clin. Invest. 91:1005-1010.

Address correspondence to Christian Kebelmann-Betzing, Department of Pediatric Oncology/Hematology, Virchow Medical Center Charité, Humboldt-University, Augustenburger Platz 1, 13353 Berlin, Germany. Internet: keb@ ukrv.de 